\title{
Cenozoic tectonics of the Western Approaches Channel basins and its control of local drainage systems
}

\section{Inversion cénozoïque des Approches Occidentales de la Manche et contrôle régional du réseau de drainage.}

\author{
Pascal Le Roy ${ }^{1,}$, , Claire Gracia-Garay ${ }^{2}$, Pol Guennoc ${ }^{3}$, Jean-François Bourillet ${ }^{4}$, Jean-Yves Reynaud ${ }^{5}$, \\ Isabelle Thinon ${ }^{3}$, Patrick Kervevan ${ }^{1}$, Fabien Paquet ${ }^{3}$, David Menier ${ }^{6}$ and Cédric Bulois ${ }^{7}$ \\ 1 Université Européenne de Bretagne, Université de Brest, CNRS-UMR 6538 Domaines Océaniques, Institut \\ Universitaire Européen de la Mer, Place Copernic, 29280 Plouzané \\ ${ }_{2}^{2}$ Institut de géologie et de paléontologie, UNIL BFSH2, CH-1015 Lausanne, Suisse \\ ${ }^{3}$ BRGM, Orléans, 3 av. Claude Guillemin, BP 36009, 45060 Orléans cedex 2 \\ ${ }^{4}$ IFREMER, 29280 Plouzané \\ ${ }^{5}$ MNHN, Département Histoire de la Terre, 43 rue Buffon, 75005 Paris \\ ${ }^{6}$ Université de Bretagne Sud, SOLITO, Rue Yves Mainguy, 56017 Vannes cedex \\ ${ }^{7}$ UCD School of Geological Sciences, University College Dublin, Belfield, Dublin 4, Ireland \\ *: Corresponding author : Pascal Le Roy, email address : leroy@univ-brest.fr
}

\begin{abstract}
:
The geology of the Channel Western Approaches is a key to understand the post-rift evolution of the NW European continental margin in relation with the Europe/Africa collision. Despite considerable evidence of Tertiary tectonic inversion throughout the Channel basin, the structures and amplitudes of the tectonic movements remain poorly documented across the French sector of the Western Approaches. The effect of the tectonic inversion for the evolution of the "Channel River", the major system that flowed into the English Channel during the Plio-Quaternary eustatic lowstands, also needs to be clarified. Its drainage basin was larger than the present-day English Channel and constituted the source of terrigenous fluxes of the Armorican and Celtic deep sea fans. A lack of high-resolution seismic data motivated the implementation of the GEOMOC and GEOBREST cruises, whose main results are presented in this paper. The new observations highlight the diachronism and the contrast in amplitudes of the deformations involved in the inversion of the French Western Approaches. The tectonic inversion can be described in two stages: a paroxysmal Paleogene stage including two episodes, Eocene (probably Ypresian) and Oligocene, and a more moderate Neogene stage subdivided into Miocene and Pliocene episodes, driven by the reactivation of the same faults. The deformations along the North Iroise fault (NIF) located at the termination of the Medio-Manche fault produced forced folds in the sedimentary cover above the deeper faults. The tectonic inversion generated uplift of about $700 \mathrm{~m}$ of the mid-continental shelf south of the NIF. The isochron map of the reflectors bounding the identified seismic sequences clearly demonstrates a major structural control on the geometry of the Neogene deposits. First, the uplift of the eastern part of the Iroise basin during the upper Miocene favoured the onset of a broad submarine delta system that developed towards the subsiding NW outer shelf. The later evolution of the 'palaeovalley' network corresponding to the western termination of the "Channel River" exhibits a 'bayonet' pattern marked by a zigzagging pattern of valleys, with alternating segments orientated $\mathrm{N} 040^{\circ} \mathrm{E}$ and $\mathrm{N} 070^{\circ} \mathrm{E}$, controlled by Neogene faulting. The palaeovalley network could have begun during Reurevian or Pre-Tiglian sea-level lowstands, which exposed the entire shelf below the shelf edge. The amplitude of the sea-level fall is assumed to have been magnified by uplift of the Iroise basin, followed by later tilting of the outer shelf, as observed in many other examples documented along the North Atlantic margins.
\end{abstract}


Keywords : English Channel, Western Approaches basins, Cenozoic, palaeovalley, seismic stratigraphy, tectonic inversion.

\section{Résumé :}

Le domaine des Approches Occidentales de la Manche constitue une zone clé pour caractériser l'évolution post-rift des marges continentales NW européennes associées à la collision Afrique/Europe. Malgré les divers témoins des inversions cénozoïques jalonnant le pourtour de la Manche, la structuration et l'amplitude des mouvements demeurent néanmoins incertaines au sein de la partie méridionale française des Approches Occidentales. II en est de même sur le rôle de l'inversion de la Mer du Nord dans la mise en place du Fleuve Manche qui drainait un bassin versant bien supérieur à la Manche actuelle durant les grandes régressions plio-quaternaires et alimentait les éventails sous-marins Celtique et Armoricain en bas de pente. La réalisation des campagnes de sismique-réflexion Haute Résolution GEOMOC et GEOBREST03 dont les résultats font l'objet de cet article permettent de répondre à ces questions en complétant la connaissance géologique de la Manche. Les nouvelles observations soulignent le diachronisme et le contraste de l'amplitude des mouvements du système de failles associées à l'inversion du bassin d'Iroise. Celle-ci se fait en deux épisodes : un épisode paroxysmal paléogène décomposé en deux phases, éocène (Yprésien probable) et oligocène, et un épisode néogène plus modéré réactivant partiellement les structures impliquées antérieurement. Les déformations se concentrent le long de l'accident nord Iroise (NIF) situé dans le prolongement de la faille Médio-Manche et entraîne localement des plissements de la couverture sédimentaire à l'aplomb des accidents profonds. L'inversion induit ainsi un soulèvement de près de $700 \mathrm{~m}$ du plateau médian situé au sud de l'accident nord Iroise. La cartographie isochrone des séquences sismiques identifiées démontre également le contrôle majeur des structures tectoniques sur la mise en place des dépôts néogènes. Le soulèvement de la partie orientale du bassin favorise ainsi la mise en place de vaste prismes progradants d'âge miocène supérieur, et contrôle le développement postérieur du réseau des paléo-vallées constituant l'extrémité occidentale du fleuve Manche. Ce réseau présente une géométrie en baïonnette marquée par de brutaux changements de directions variant de N40 à N70, cette dernière direction caractérisant la plus grande partie des failles néogènes associées au bassin d'Iroise. Les paléo-vallées se seraient développées lors d'une chute du niveau marin au-delà du rebord de plate-forme et la stratigraphie établie à travers cette étude amène à placer le début des incisions au Pliocène (Reurévien ou pré- Tiglien). La chute amplifiée par l'inversion du bassin d'Iroise serait suivie d'un basculement tardif de la plate-forme externe à l'instar des observations réalisées sur de nombreuses marges du pourtour nord atlantique.

Mots clés : Approches Occidentales, Cénozoïque, paléo-vallée, stratigraphie sismique, inversion tectonique. 


\section{INTRODUCTION}

The Western Approaches is an area of the W European continental shelf located at the transition between the Western English Channel and the northern termination of the Bay of Biscay. It is surrounded by the offshore extension of the Cornubian Massif to the north and the Armorican Massif to the south. It contains WNW-ESE-trending sedimentary basins (the Iroise Basin or Brittany Trough and the Western Approaches Basin), where Palaeozoic to Cenozoic deposits are up to $7 \mathrm{~km}$ thick [Evans, 1990] (Fig. 1). The present-day structural style of these basins was acquired during the Cenozoic tectonic inversion induced by the Africa/Eurasia collision [Ziegler, 1982, 1987, 1990; Curry \& Smith, 1975 ; Curry et al., 1978 ; Ruffel, 1995 ; Van Vliet_Lanoë et al., 2004]. Although the total deformations related to this inversion are relatively moderate through the Western Approaches Basin [Bois et al., 1991], significant compression occurred along its southern border (Aldernay-Ushant fault zone; Fig. 1), where uplift of the inverted Iroise Basin could have reached $1400 \mathrm{~m}$ [Hillis, 1991; Menpes \& Hillis, 1995]. However, in contrast to the good structural and stratigraphic descriptions of the English part of the basin, the detailed stratigraphy and tectonics of the French sector remain poorly documented.

The Cenozoic stratigraphy in the northern Western Approaches shows a wide, prograding Miocene progradational wedge of dominantly shallow-marine bioclastic formations (Jones, Cockburn) passing into a siliciclastic shelf-margin delta topped by an unconformable cut-andfill deposit preserved at the outer shelf (Little Sole) [Bouysse et al., 1975 ; Evans \& Hugues, 1984]. In the French sector, the cut-and-fill deposit is less developed and mainly infills palaeovalleys [Bouysse et al., 1976 ; Pantin \& Evans, 1984; Reynaud et al., 1999a ; Peyre, 1997], which have been interpreted as the outermost part of the 'Channel River', that flowed through the English Channel during the Late Quaternary sea-level lowstands [Gibbard et al., 1988] and supplied sediments to the Armorican and Celtic Deep Sea fans [Auffret et al., 1999; Zaragosi et al., 2000; Zaragosi, 2001; Bourillet et al., 2003]. However, there is no evidence of any connection between the 'Channel River' remnants in the central and eastern Channel [Auffret et al., 1982; Lericolais, 1997; Lericolais et al., 2003; Gupta et al., 2007] and the Western Approaches palaeovalleys. This loss of continuity might be explained by the strong ravinement and erosion associated to the early stages of the post-glacial transgressions of the Late Quaternary [Reynaud et al., 1999b]. The age of the incisions also remains 
hypothetical, varying from the Messinian to the Pleistocene [Pantin \& Evans, 1984;

Lericolais, 1997; Reynaud et al., 1999a; Bourillet et al., 2003].

Because glacioeustatic sea-level drops before the Middle Pleistocene were not as low as during the last glacial stages [e.g.; Shackleton and Opdyke, 1973; Shackleton, 1987], this range of ages for valley incision at the shelf margin allows us to consider that basin inversion may be responsible for the valley incisions during the Alpine tectonic phase. However, this possibility remains to be demonstrated. This circumstance motivated the GEOMOC and the GEOBREST cruises in 2002 and 2003. The results presented in this paper are supported by the interpretation of these new data, including high-resolution seismic lines coupled with reinterpretation of previous seismic studies led by the BRGM, IFREMER, and the BGS detailed logs of industrial wells provided by TOTAL co. The isochron maps of the Neogene seismic sequences calibrated with the seismic stratigraphy established for the English sector allow clarification of the chronology and the amplitudes of the Western Approaches inversion, and provide evidence of the tectonic control of the palaeovalley incision.

\section{GEOLOGICAL SETTING AND PREVIOUS RESEARCH}

The French sector of the Western Approaches is located between the western limit of the English Channel (defined by the line Land's End/Corsen Headland) and the shelf break above the Meriadzek Terrace (Fig. 1). Mesozoic and Cenozoic formations that crop out on the seabed beneath surficial sediments delimit two NW-SE-trending basins, surrounded by the offshore extension of the Cornubian Massif to the north and the Armorican Massif to the south. In the north, the Western Approaches Basin (WAB) corresponds to a syncline opening to the southwest (the 'synclinorium médian') with Miocene filling [Andreieff et al., 1972, Bouysse et al., 1974; Ziegler, 1982, 1987; Chapman, 1989; Bois et al., 1991]. The northern flank of the WAB corresponds to the Lizard-Dodman-Start Thrust; it is composed of a series of south-dipping thrusts that obducted a slice of ocean floor constituting the ophiolitic Lizard Complex setting in the Late Devonian during the closure of a small ocean basin bounded by the Rhenohercynian margin [Shail et al., 2009]. In the south, the Mesozoic Iroise Basin or Brittany Trough is limited by two major $\mathrm{N}^{\circ}{ }^{\circ}$ E-trending fault zones: the North Iroise Fault zone (NIF or 'Mid-Channel' Fault) and the South Iroise Fault zone (SIF) located at the extension of the major Alderney-Ushant fault [Bois et al., 1991]. The shallow geology of the 
western part of this basin remains poorly known due to a lack of high-resolution seismic data [Bouysse \& Horn, 1972; Ziegler, 1987; Bois et al., 1991].

\section{The inversion phase}

The first evidence of the Europe/Africa collision described across the Western Approaches is assumed to have been a consequence of the partial closure of the Bay of Biscay and the intensified phase of Pyrenean orogeny at the end of the Eocene [Montadert et al., 1979; Olivet et al., 1984; Olivet 1996; Thinon, 1999]. This induced a sinistral strike-slip reactivation of the Alderney-Ushant fault zone and corresponds to a sedimentary hiatus from the Middle Eocene to the Upper Eocene on the deep Celtic and Armorican margin basins [Evans, 1990; Thinon, 1999]. During the Oligocene, the main phase inversion of the Western Approaches produced the uplift of a SW-NE-trending anticlinorium in the Iroise Basin, controlled by the North and South Iroise faults. One last inversion phase took place during the Late Miocene after a period of relative tectonic quiescence and is linked to the Alpine phase. It is assumed to affect the entire basin and to have caused an uplift of the outer shelf of the English sector during the Pliocene [Evans \& Hugues, 1984].

\section{The palaeovalleys and the 'Channel River'}

The palaeovalley network is well documented and mapped across the outer shelf between isobath $140 \mathrm{~m}$ and the shelf break at about 180-200 m bpsl [Peyre, 1997; Reynaud et al., 1999a; Bourillet et al., 2003]. The palaeovalleys are up to several tens of kilometres wide and their depths increase by up to $50 \mathrm{~m}$ seawards. The valleys trend towards the SSW, slightly oblique to the present-day slope direction of the shelf [Bouysse et al., 1976], but some valleys are curved to the NW upstream, suggesting the existence of a major tributary that might have been in the north of the Western Approaches Basin (Fig. 2). Nevertheless, such a tributary remains undocumented even though a presumed talweg was located throughout the middle shelf by Bouysse and Horn [1972] (Fig. 2). According to the few existing seismic records, the eastern valleys pinch out 10 to $40 \mathrm{~km}$ before the shelf break, whereas the western valleys are connected to the canyon network. These canyons constitute the main drains that feed the Celtic and Armorican Deep Sea fans, but only the Armorican fan is entirely supplied by the Western Approaches palaeovalleys [Bourillet et al., 2003].

The detailed architecture of the infilling series of one of the palaeovalleys shows a set of eight depositional sequences, each comprised of lowstand fluvial channels to transgressive estuarine or marine flat-bedded deposits [Reynaud et al., 1999a]. The stacking pattern of the sequence set 
reflects a progradational-retrogradational succession assumed to have been produced during at least the last five, high-order sea-level cycles [Reynaud et al., 1999a]. In the absence of core samples, the nature and timing of valley fills is still a subject of much discussion. Bouysse et al. [1976] consider an incision during the early Pleistocene, implying a major sea-level drop below $-240 \mathrm{~m}$ bpsl. However, that level is two times greater than the amplitude of global sea-level lowstands expected for the Late Pleistocene glacial periods [Waelbroeck et al., 2002]. More likely, the valley incision may have started either during the Pliocene [Evans \& Hugues, 1984; Pantin \& Evans, 1984], with the Pretiglian lowstand coinciding with a significant cold climate event but not matching a sharp sea-level fall [Lericolais, 1997], or during the Mid-Reurevian lowstand [Reynaud et al. 1999a]. These hypotheses imply a moderate eustatic sea-level fall and therefore a significant subsidence rate of the continental margin of about $80 \mathrm{~m}$ to $100 \mathrm{~m} / \mathrm{Ma}$ to explain the depths of the base of incisions located over $-200 \mathrm{~m}$ bpsl at the shelf break. Considering a lower subsidence rate of 10 to $25 \mathrm{~m} / \mathrm{Ma}$ much in accord with classic models of thermal subsidence for mature passive margins [McKenzie, 1978], Bourillet et al. [2003] considered the incision may be of Messinian age. Onshore, the Late Miocene is also known as a period of valley incision in Central and Southern Brittany, with two stages dated as Late Serravalian to Tortonian and Late Tortonian to Early Messinian [Van Vliet-Lanoë, et al., 1998; Brault et al., 2004].

\section{NEW RESULTS}

\section{Data and methods}

During the GEOMOC and GEOBREST cruises, $2000 \mathrm{~km}$ of seismic lines were acquired using a 1000J sparker system and a six-channel streamer (Figs. 2 to 6). Seismic processing (stacking, filtering Butterworth 200-500 Hz) was carried out with Seismic Unix and SPW (Parallel Geosciences Corporation) software. Seismic lines were interpreted using Seisvision and Kingdom Suite software (Seismic micro technology INC). Older available data collected from 1968 to 1998 across the French sector of the Western Approaches (Table 1) were integrated in the database.

Seismic data were completed by summarized reports of seven oil drills (Garlizenn1, Kulzenn, Levneg1, Lenkett1, Lizenn1, Rea Gwenn1, and Yar Vor) and 1/500 well-logging records of the Garlizenn1 and Levneg1 wells provided by TOTAL. The results of the industrial coring F1 located west of Ouessant (Ushant) Island and a composite log of the BGS 81/2 core located close to the English/French water line were also used [Bignot et al., 1989; Evans, 1990]. 
Finally, available geological maps of the survey area have completed the data set [BRGM 1/250 000 Ouessant: Lapierre \& Bouysse, 1975, BEICIP 1/250 000 Western Approaches, IGS 1/250 000 Lizard].

Three isochron maps (Figs. 7 to 9) were drawn in order to describe the Neogene sedimentary distribution through the French sector and to specify the link with the basin inversion. The faults shown on each map correspond to the faults affecting the mapped reflector.

The Garlizenn Well, located along the MOC04 seismic line, was the most useful one for constraining the facies and chronology of the seismic record (Fig. 10). The time-depth conversion was performed using the SONIC well log available for Palaeogene deposits and completed for Neogene deposits from complementary Sonic records provided by Evans [1990]. A time-depth curve was established using the following velocities: $2180_{+/ 2} 200 \mathrm{~m} / \mathrm{s}$ for the Pliocene, $2540_{+/-200} \mathrm{~m} / \mathrm{s}$ for the Miocene, and $2910_{+/-100} \mathrm{~m} / \mathrm{s}$ for the Oligocene.

\section{Stratigraphy}

Two major seismic sequences, S1 and S2, separated by a pronounced regional-scale erosional unconformity, $\mathrm{R} 1$, are recognized on the seismic lines as shown by the representative MOC 12 section (Fig. 3).

The lower megasequence, S1, partially masked by the seabed and the multiple reflectors of the upper layers, is characterized by intensive deformations. Three to four inner sequences are locally identified according to their outer geometry and bounding unconformities. The basal sequence $\mathrm{S} 1 \mathrm{a}$ is thicker than the other $\mathrm{S} 1$ inner sequences and shows parallel reflectors typified by moderate frequencies and continuities and variable amplitudes. S1a exhibits a succession of northwestward-verging asymmetric antiforms of kilometric wave with truncated tops. Antiforms are locally faulted and alternate with synforms whose geometries could not be fully imaged due to a lack of seismic penetration. S1a is locally unconformably overlain by S1b on the flanks of the antiforms, and the latter is conformably overlain by S1c. The S1b reflectors exhibit low continuity, moderate amplitude, and high frequency and onlaps the top of U1a, whereas the S1c reflectors have moderate continuity, high amplitude, and lower frequency. Both sequences show a set of non-parallel stratigraphic surfaces with upward-decreasing dip from older to younger levels, producing a wedge-like geometry. This pattern is typical of syntectonic deposits at the front of a growth fold [Williams et al., 1989; Ford et al., 1997]. The 
spatial arrangement of the reflectors corresponds to growth strata with onlap (S1b) and offlap (S1c) patterns that have recorded the development of the associated fold.

A fourth sequence, S1d, also characterized by wedge-like geometry, is locally observed on the MOC06 line. This geometry seems mostly induced by the rotation of the frontal anticline forelimb to the SSE even though the activity of the fault bordering the NNW flank of an antiform structure could also have accommodated the deformation (Fig. 4). S1a was previously sampled and mapped as it crops out on the seabed to the east [Andreieff et al., 1969; Bouysse \& Horn, 1972; Bignot et al., 1989]. It corresponds to Upper Cretaceous-Palaeocene (Thanetian) chalks and silty marls, which is in agreement with the interpretation of the same strata in the English sector [Evans \& Hugues, 1984]. Sequence S1b, resting unconformably above S1a, is probably of Eocene age and corresponds, at the Garlizenn well, to Ypresian clays that grade upwards to marls and glauconitic, slightly sandy limestones of Upper Eocene age. The Garlizenn well data could not constrain the ages of S1c and S1d because their burial exceeds the penetration of the seismic sparker at the well location, but their depth at the well location can be inferred by comparing crossing information on nearby seismic lines. In our opinion, they correspond to the Oligocene biodetrital limestones logged in the Garlizenn well (Fig. 6). These stratigraphic attributions refine the general framework of the Palaeogene established by Bouysse et al. [1974].

The upper megasequence $\mathbf{S} 2$ shows stacked sequences with larger spatial distribution and locally lateral facies transitions (Fig. 5: MOC08). The basal sequence S2a is composed of a set of horizontal, conformable reflectors of variable amplitude and frequency and high continuity. In the NW, it consists of large clinoforms prograding towards the NW in the syncline of the Western Approaches Basin. S2a is topped by a well-marked reflector (R2a) extending through the whole outer shelf and corresponding locally to an erosional unconformity. It is overlain by the S2b sequence showing reflectors of amplitude, frequency, and continuity similar to those in S2a. S2b is composed of a set of large sigmoidal clinoforms with lateral extensions of 5 to 10 $\mathrm{km}$ and moderate NW dips of $0.5^{\circ}$ to $1.5^{\circ}$. Unconformities within S2b indicate three subsequences (S2b1 to S2b3), also well individualized in the NW (Fig. 3: MOC12). The upper sequence S2c has a channel-fill geometry, bounded at the bottom by the well-marked erosional unconformity R2b. It exhibits reflectors ranging from chaotic to oblique clinoforms, suggesting a channel-fill geometry. The comparison of the acquired seismic database with sparker lines 78/04/53 in the English sector indicates that S2c corresponds to the Upper Little Sole Formation defining the infill of the palaeovalleys, and S2b2 and S2b3 to the Cockburn Formation, 
characterized by similar downlapping reflectors and sigmoidal structures, interpreted as shelf deltas emplaced in water depths ranging from 40 to $80 \mathrm{~m}$ (Fig. 6, Table 2) [Evans \& Hugues, 1984; Evans, 1990]. S2b1 and S2a correspond to the Jones Formation, although the surface between $\mathrm{S} 2 \mathrm{~b} 1$ and $\mathrm{S} 2 \mathrm{~b} 2$ is not as prominent as in the English sector and is restricted to the NW part of the Iroise Basin. The projected contact between S2b1 and S2b2 at the Garlizenn well points to a sharp contact between a glauconitic limestone interbedded with shelly sands and foram-rich oozes (S2b2-S2b3) on top of a chalky mudstone with considerable bryozoan and bivalve debris (S2b1). This matches the results of Evans and Hugues [1984], who described the Cockburn as bioclastic and the Jones as much muddier. However, at the Garlizenn well, correlation indicates that the upper part of the Jones Formation is Upper Miocene in age instead of Middle Miocene, as previously assigned by Evans and Hugues [1984], based on the planktonic foraminifera zones N11-N12. It is likely that the long time-span (Oligocene-Upper Miocene) attributed to the deposition of the Jones Formation is related to the progressive offset of the deltaic bodies from one sub-basin to the other, away from the main faults, as inversion progressed.

The megasequence boundary between $S 1$ and $S 2$ corresponds to the top Palaeogene unconformity (R1). This surface was uplifted following a horstlike spur sided by the NIF zone, and on top of which the Neogene is absent (Fig. 7). The R1unconformity is offset by about 150 ms (two-way time) across the NIF, which is indicative of the paroxysm of the Iroise Basin inversion. This spur is the western end of the inverted part of the basin partially described to the east [Andreieff et al., 1969; Bouysse \& Horn, 1972; Bouysse et al., 1975]. The intra-Jones unconformity (R2) follows the same structural pattern (Fig. 8). However, its lower relief indicates progressive inactivation and flooding of the horst. Sedimentation has also advanced seawards along the Iroise syncline and the axis of the basin appears to have shifted to the south in the vicinity of the NIF zone. The eastern segment of this fault zone remained active during the end of deposition of the Jones Formation. During the Pliocene, the NIF zone still controlled the geometry of the Iroise Basin and the northern syncline as the conduit of the Channel River, as shown by the unconformity at the base of the Upper Little Sole (R2c; Fig. 9). This is evidenced by the southward deflection of the valleys originated from a single, large tributary located at the southern border of the Western Approaches Basin.

\section{DISCUSSION}




\section{Age and amplitude of the inversion along the border of the Iroise Basin}

Palaeogene stage.- The new seismic data allow documentation of the tectonic inversion of the Iroise Basin and an accurate division of this phase into two distinct stages: a paroxysmal Palaeogene stage (marked by the R1 unconformity) and a Neogene stage (Table 2). The westward section of the R1 reflector evolves into a paraconformity surface and shows that deformations and inverted structures centred along the former normal faults controlling the formation of the Iroise Basin (NIF and SIF zones). The evolution of the Palaeogene inversion can be deduced from the geometry of the sequences preserved on the anticline flanks. The unconformity separating the S1a and S1b sequences points to the onset of the Palaeogene inversion during the Eocene (probably the Ypresian), but then restricted to moderate folding inducing a broad uplift corridor where Eocene deposits were confined (Fig. 3). The second, paroxysmic Palaeogene stage, corresponding to the Oligocene Channel inversion, started at the end of deposition of S1c. It mainly affected the shelf around the NIF zone, which was uplifted and eroded down to the Lower Cenomanian units that crop out on the seabed along tight anticlines [Bouysse \& Horn, 1972]. The deformation produced growth strata associated to fold structures located along the NIF and SIF zones. They correspond to forced folds that developed in the competent chalks of the Upper Cretaceous and located above the deeper basement faults of the basin. Finally, the basin was uplifted as a 'keystone block' and developed internal folding of the Upper Cretaceous and Palaeogene cover in the hanging walls to the NIF and SIF zones. Faults are more developed in the southern part of the basin. Such a geometry and tectonic inversion structures were previously described in the UK Wessex Basin [Underhill \& Paterson, 1998] and southern North Sea [Badley et al., 1989].

This tectonic stage ended in the Burdigalian, as evidenced by Bryozoan-rich calcarenites resting above the R1 unconformity in the F1 well. Oceanwards (Garlizenn1 well) and in the centre of the Iroise Basin (ReaGwenn well), this stage is not recorded and Eocene and Oligocene series reach up to $500 \mathrm{~m}$ in thickness without significant unconformities.

Neogene stage.- The Neogene inversion episode is mainly characterized by a local reactivation of inherited Palaeogene structures. It is marked by a broad folding of the S2a (Jones) and S2b (Cockburn) sequences above Palaeogene anticlines and tilted blocks (Fig. 5 and Fig. 8). S2a, attributed to the Lower to Middle Miocene, does not evidence a syntectonic nature and the R2a erosional unconformity surface separating $\mathrm{S} 2 \mathrm{a}$ and $\mathrm{S} 2 \mathrm{~b}$ does not appear to be induced by local uplifted tectonic structures (Table 2). Its origin is more probably linked to a major marine regression possibly likely corresponding to the upper Serravalian sea-level fall [Haq et al., 
1987, 1988]. In contrast, the tectonic uplift of the folded zones was renewed during the deposition of S2b, assumed to be Late Miocene to Pliocene in age, as expressed by the spatial arrangement of the unconformities and sedimentary wedge system, composed of growth onlap and growth overlap strata along the hanging wall of the NIF zone (Fig. 11). The uplift on the borders of the Iroise Basin brought about (i) a concentration of sediment fluxes in the syncline axis and (ii) increased hydrodynamics. As a consequence, the submarine deltas of the Cockburn Formation are coarser-grained and pass locally basinwards into ridge-like deposits running parallel to the syncline. These features, previously mentioned by Evans and Hugues [1984], make sense in the light of the structural evolution of the Channel inversion. This evolution lasted until the formation of S2c (Fig. 9).

Amplitude of inversion.- What is the total amplitude of the uplift associated to the inversion of the Iroise Basin? If we consider a homogeneous sedimentation rate during the Late Cretaceous and Palaeocene preceding the Eocene inversion stage, the minimum amplitude of the uplift can be deduced from the eroded thickness of Palaeogene and Cretaceous rocks along the bounding fault zones, which is about $650 \mathrm{~m}$ at Garlizenn1 well. The additional Neogene uplift seems to have induced a displacement of about $50 \mathrm{~m}$ deduced from deformations of Neogene sequences. Thus, the total amplitude is considered to be close to $700 \mathrm{~m}$ and this estimation represents minimum values neglecting possible eroded deposits from the Lutetian to the Aquitanian. This value remains lower than the 1000 to 1400 m estimated by Menpes and Hillis [1995] for the Iroise Basin based on burial/depth anomalies they deduced from compaction analyses. It is also much lower than the estimations of Ziegler [1987, 1990], who considered a structural relief of some $3000 \mathrm{~m}$, implying massive erosion of Lower Cretaceous layers and a significant thickness of Tertiary deposits preceding the paroxysmal inversion episode over the whole basin. These two latter points are not confirmed by the seismic data of the Iroise Basin.

\section{Controls of the palaeovalley network}

Structure and lithology.- The structural control of the palaeovalleys consists in the confinement of the Channel River in the axis of the grabens and synclines flanking the NIF zone to the south of the inverted basins (Fig. 7 and 8), following a path that can be traced out from the Hurd Deep in the Central Channel to the west of the Iroise Basin (Fig. 1). The inversion lasted until the valleys were incised, probably in the Pliocene, so that the topography could have kept the structural imprint even under the action of the marine ravinement that cut off the deposits raised above the level of wave erosion. This topographic control explains the southward curving of the preserved upstream part of the valleys flanking the NIF to the south (Fig. 9), whereas the 
overall Western Approaches slope dip is more to the WSW. The zigzag pattern of the valleys also reflects the alignment of some valley segments along the Neogene faults, which are mostly orientated $\mathrm{N} 40^{\circ}$. Furthermore, seismic analysis reveals that incision focused inside the weakly consolidated Upper Miocene limestones and Pliocene carbonate oozes of S2b2 and S2b3 (Cockburn Formation). Abrupt variations of about $15 \mathrm{~m}$ in the incision depths along the NIF zone suggest the deformations remained active during the Pliocene and Quaternary, although more data would be required to better quantify the related offset.

\section{Timing.}

The chronostratigraphic interpretation of identified seismic sequences suggests that the upper Cockburn Formation is younger in the Iroise Basin than in the English sector. Although Powell [1988] attributed it to the late Serravalian-early Tortonian in the BGS 72/ 10-1A well, the Garlizenn well correlation indicates that S2b3 (top Cockburn Formation) is in the Pliocene. This implies, in turn, that the age of valley incision is either Pliocene or Pleistocene; that is to say, younger than the Messinian age previously proposed by Bourillet et al. [2003]. The Serravallian-Tortonian lowstand assumed to be responsible for the aerial incision of the southern Armorican shelf could not be considered for these palaeovalleys either [Paquet et al., 2010]. Furthermore, as the deltaic deposits corresponding to the underlying S2b2 and S2b3 sequences (Cockburn Formation) were assumed to be emplaced in water depths ranging from 40 to $80 \mathrm{~m}$ [Evans \& Hugues, 1984], the amplitude of the sea-level fall necessary for the emergence of the outer shelf does not need to be very great. Reynaud [1996] and Reynaud et al. [1999a] consider a main incision phase during the mid-Reurevian third-order eustatic fall (ca. 2.9 Ma). Neither do the new results exclude the Pretiglian eustatic fall (2.5-2.4 Ma) also recorded onshore [Morzadec-Kerfourn, 1990] and suggested by Lericollais [1997] as the incision trigger. The emersion of the shelf during the Pliocene would have been facilitated by the tectonic inversion and the consequent uplift of the block south of the NIF. Nevertheless, a high to very high subsidence rate is required to explain the present-day depth of the valleys ( 70 , 80 or $>170 \mathrm{~m} / \mathrm{Ma}$ for the Pliocene and the Lower and Middle Pleistocene). Subsidence acceleration during the Pliocene and Quaternary is reported from other margins of the North Atlantic and North Sea [Cloething et al., 1990; Praeg et al., 2005]. Such vertical movements correspond to oceanward tilting of the outer shelf and the correlative uplift of the inner shelf, with vertical displacements of up to several hundred metres over horizontal distances of hundreds of kilometres [Praeg et al., 2005]. The related rapid subsidence at the shelf edge could explain the preservation of the cumulative fill of height depositional sequences vertically 
stacked in a single valley [Reynaud et al., 1999a]. Furthermore, the mean slopes of palaeovalley talwegs exceed $0.1^{\circ}$ across the gently dipping outer shelf, which is a higher value than commonly observed for drainage systems that developed on a margin recording minimal subsidence and tectonic quiescence, such as the New Jersey drainage system [Nordfjord et al., 2004].

\section{CONCLUSIONS}

The new seismic data collected during the GEOMOC and the GEOBREST cruises performed through the French sector of the Western Approaches has provided greater information on the nature of the tectonic inversion of the Iroise Basin and its implication for the Neogene sedimentation and development of the lower palaeovalleys of the 'Channel River'.

The new observations indicate the diachronism and the contrast of amplitudes of the fault system controlling the basin inversion. Tectonic inversion can be described in two main stages : (i) a paroxysmal Palaeogene stage including two episodes: Eocene (probably Ypresian) and Oligocene, with forced faults located above the deep basement faults zones of NIF and SIF; and (ii) a more moderate Neogene stage corresponding mainly to the Late Miocene and Pliocene, characterized by reactivation of tectonic structures previously involved and focussed along the North Iroise Fault. These inversion stages contributed to an uplift of about $700 \mathrm{~m}$ of the shelf south of the North Iroise Fault while the outer shelf was still subsiding. This favoured (i) in the Late Miocene, the onset of a submarine delta prograding inside the Iroise Basin syncline; (ii) in the Pliocene, the incision of a network of fluvial valleys.

The seismic coverage allowed us to map the palaeovalley network across the median shelf, showing that the valleys spread out from a single tributary sided by the Iroise faults. South of the North Iroise Fault, the valleys flow more southerly than expected from the regional shelf slope due to the continued effect of uplift of the fault zone at the time of valley incision. The rapid drowning of the valleys at the shelf edge during the Pliocene and Quaternary would therefore be related to an abrupt increase in subsidence, as observed also along other margins of the North Atlantic.

ACKNOWLEDGMENTS

The authors are very grateful to Olivier Averbuch and an anonymous reviewer for their careful examination of a previous version of this paper and for their helpful comments. The authors are also very grateful to the captain, Renaud Le Bourhis, and crew of the INSU/CNRS R/V "Côtes 
de la Manche". We also thank the scientists and technicians for their participation in the project and the cruise: Jacques Bégot, Jean-Pierre Réhault, Joël Rolet Gwenaël Jouet, Carlos Pallares, Cécile Idier (Univ. brest), and the students of UBO. We are also grateful to Christine Maurin for the improvement of the english writing.

\section{REFERENCES}

AndreiefF P., Boillot, G., Buge, E. \& GennesseauX, M. (1969). - La couverture sédimentaire tertiaire à l'Ouest et au Sud-Ouest du Massif Armoricain. - Bull B.R.G.M. (2), IV, 4, 23-37.

ANDREIEFF P., BOUYSSE P., HORN R. \& MONCIARDINI C. (1972). - Contribution à l'étude géologique des approches occidentales de la Manche, Mémoire du B.R.G.M. France, 79, 31-48.

Auffret G. -A., Droz L., Zaragosi S., Unterseh S., Bourillet J. -F. \& BAltZer A. (1999). - The Celtic deep sea fan : bathymetry imagery and cenozoic development. North-East Atlantic slope processes: multi- disciplinary approaches, incorporating TTR-8 post cruise Conference. 4th ENAM II Workshop , 432, contourites and bottom currents, 24-27 January 1999, Southampton. Abstract, 15.

Auffret J.-P., ALduc D. \& LARsonneur C. (1982) - La Manche orientale, 1:500000; Paleovallees et banc sableux. Carte Geol. Marge Cont. Fr., France. 8 p.

BADLEY M.E., PRICE J.D. \& BACKSHALL, L.C, (1989). - Inversion, reactivated faults and related structures : seismic examples from the southern North Sea. In : CoOper M.A., WiLliams G.D. eds, Inversion tectonics. Geological Society Special Publication, 44, $201-219$.

Bignot G., Poignant A. \& GuYAdER J. (1989). - Les foraminifères du Thanétien et du Miocène de la mer d'Iroise, rencontrés en sondage au large d'Ouessant-Etude préliminaire. - Géol. de la France, 1-2, 5-10.

Bois C, CAZes M, Gariel O, Lefort J. -P, Le Gall B, Pinet B \& Sibuet J. -C. (1991a). - Principaux apports scientifiques des campagnes SWAT et WAM à la géologie de la mer Celtique, de la Manche et de la marge Atlantique. - Mémoires de la Société Géologique de France, 159: 185217.

BOILlOt G., HORN R. \& LEFORT J.-P. (1972) - Evolution structurale de la Manche occidentale au Secondaire et au Tertiaire. (Colloque sur la géologie de la Manche, 1971). - Mém. B.R.G.M., Fr, 79, 79-86

Bois C, GARIEL O, MASClE A \& SCHROEDER I. (1991). - Les bassins sédimentaires de mer Celtique et de Manche: apport des profils sismiques SWAT. - Mémoires de la Société Géologique de France, 159: 25-66.

BourilletJ. -F., Reynaud, J. -Y., BAltZER, A. \& ZARAgosi, S. (2003). - The 'Fleuve Manche': the submarine sedimentary features from the outer shelf to the deep-sea fans. - J. Quaternary Sci., 18, 261-282.

BOUYSSE P. \& HORN R. (1972). - La géologie du plateau continental autour du Massif Armoricain. - Bull. du B.R.G.M. (2) , IV, 2, 3-17.

Bouysse P., Horn R., LeFORT, J.-P. \& LE LANn F. (1975). - Tectonique et structures post-paléozoïques en Manche occidentale. - Phil. Trans. R. Soc. Lond., A., 279, 41-54

Bouysse P, Horn R, LAPIERRE F \& Le LANn F. (1976). - Etude des grands bancs de sable du Sud-Est de la Mer Celtique. - Marine Geology, 20: 251275 .

BouysSE P., HoRn R., LEFORT J.-P. \& LE LANN F. (1974). - Tectonique et Structures post-paléozoïques en Manche Occidentale. - Bull. du B.R.G.M., $2, \mathrm{IV}, 2,67-71$.

BOUYSSE P., HORn R., LefORT J.P. \& LE LANn F. (1975). - Tectonique et Structure post-paléozoïques en Manche Occidentale. - Philos. Trans. R. Soc. Le London, 279 : 41-54. 
Brault N., Bourquin S., Guillocheau F., Dabard M.-P., Bonnet S., Courville P., Este’oule -Choux J., Stepanoff F.(2004).- Mio-Pliocene to Pleistocene paleotopographic evolution of Brittany (France) from a sequence stratigraphic analysis: relative influence of tectonics and climate. - Sedimentary Geology, 163,175-210.

ChAPMAn, T.J., (1989). - The Permian to Cretaceous structural evolution of the Western Approaches Basin (Melville sub-basin), UK. In : COOPER M.A., Williams G.D. eds, Inversion tectonics. Geological Society Special Publication, 44, 177-200.Cloetingh, S., GRAdSTEIN, F.-M., KooI, H., GrANT, A.-C. \& KAMinSKI, M. (1990). - Plate reorganization: a cause of rapid late Neogene subsidence and sedimentation around the North Atlantic. - Journal of the Geological Society, London, 147, 495-506.

CURRY D. \& SMITH A.J. (1975). - New discoveries concerning the geology of the central and eastern parts of the English Channel. - Phil. Transac. Royal Soc. Lond., 279A, 155-167

CurRy D., Adams C.G., Boulter M.C., Dilley F.C.,, Eames F.E., FunNel B.M. \& Wells M.K. (1978). - A correlation of Tertiary rocks in the British Isles. - Geol Soc. London, Spec. Rep. 12, 72p.

Evans C.D.R. (1990). - United Kingdom Offshore Regional Report: the Geology of the Western English Channel and its Western Approaches. - British Geological Survey, NERC, HMSO: London, 94p.

Evans C.D.R \& HughES M.J. (1984). - The Neogene succession of the South Western Approaches, Great Britain. - Journal of the Geological Society of London, 141: 315-326.

Ford M., Williams E.A., ARToni A., Vergès J. \& Hardy S., (1997). - Progressive evolution of a fault-related fold pair from growth strata geometries. - Journal of structural Geology, 19, 3-4, 413-441.

GIBBARD P. L. (1988). - The history of great northwest European rivers during the past three millions years. - Phil. Trans. R. Soc. Lond. B318, 559-602.

Gupta S, Collier J.S, Palmer-Felgate A. \& PotTer A.. (2007). - Catastrophic flooding origin of shelf valley systems in the English Channel. Nature, 448, 342-345.

HAQ B.U., HARDENBOL J. \& VAIL P.R. (1987). - Chronology of fluctuating sea levels since the Triassic. - Science, 235, 1156-1167.

HAQ B.U., HARDENBOL J. \& VAIL P.R. (1988). - Mesozoic and Cenozoic chronostratigraphy and cycles of sea-level change. In : Sea-level changes: an integrated approach. Wilgus C., K, HAstings B.S., St CKendall C. G. et al., Eds., Special Publication 42, Society of Economic Paleontologists and Mineralogists: Tulsa; 71-108.

HILLIS, R.R. (1991). - Chalk porosity and Tertiary uplift, Western Approaches Trough, SW UK and NW French continental shelves. - Journal of the Geological Society, London, 148, 669-679.

LAPIERRE F. \& BOUYSSE P. (1975). - Carte géologique de la marge continentale française à l'échelle du 1/250000 Ouessant (I-Géologie et Structure). Edition du B.R.G.M.

LERICOLAIS G. (1997). - Evolution Plio-Quaternaire du Fleuve Manche : Stratigraphie et Géomorphologie d'une plate-forme continentale en régime périglaciaire.- Thèse de doctorat de l'Université de Bordeaux I, spécialité : géologie marine, $260 \mathrm{p}$.

LERICOLAIS G., AUFFRET J. -P., \& BOURILLET J.-F. (2003) - The Quaternary Channel River : seismic stratigraphy of its paleovalleys and deeps. - J. Quaternary Sci., 18, 245-260.

Mc KENZIE D. (1978). Some remarks on the devlopment of sedimentary basins. - Earth Planet. Sci. Lett. 40, 25-32.

MENPES R.J. \& HiLLis R.R. (1995) - Quantification of Tertiary exhumation from sonic velocity data, Celtic Sea/South-Western Approaches. In : Buchanan, J. G. \& Buchanan, P.G, Eds., Basin Inversion, Geological Society Special Publication, 88, 191-207.

Montadert L., Roberts D. -G., De Charpal O., \& Guennoc P. (1979). - Initial Reports of the Deep Sea Drilling Program, 48, US Government Printing Office: Washington, DC, 1025-1060.

MORZADEC-KERFOURN, M. -T. (1990) - De l'importance relative des transgressions et regressions marines glacio-eustatiques sur le massif armoricain. Revue Archéologique de l'Ouest, supplément no 2,37-40.

NordfJord, S., GofF, J.A., Austin JR., J.A., \& SOMmERFIELD, C.K. (2005). - Seismic geomorphology of buried channel systems on the New Jersey outer shelf: assessing past environmental conditions. - Marine Geology, 214, 339-364. 
Olivet J.-L., Bonnin J., BeuZART P. \& AuZENDE J.-M. (1984). - Cinématique de l'Atlantique Nord et Central. Centre National pour l'Exploitation des Océans: Brest.

Olivet J.-L. (1996). - La cinématique de la plaque Ibérie.- Bulletin des Centres de Recherches Exploration-Production elf-aquitaine, Pau, 20, 131195.

PANTIN H.M. \& EvAns C.D.R. (1984). - The Quaternary history of the central and southwestern Celtic Sea. - Marine Geology, 57: $259-293$.

Paquet F., Menier D., Estournès G., Bourillet J.F., Leroy P. \& Guillocheau F. (2010). - Buried fluvial incisions as a record of Middle-Late Miocene eustasy fall on the Armorican Shelf (Bay of Biscay, France) - Marine Geology, 268, 137-151

PEYRE, S. (1997). - Interprétation de profils sismiques et cartographie de paléovallées au large de Brest. - Institut Français pour la Recherche et l'Exploitation de la Mer (IFREMER), International report DRO/GM-97-13.

PowelL A.J. (1988). - A preliminary investigation into the Neogene dinoflagellate cyst biostratigraphy of the British Southwestern Approaches. - Bull. Centre de Rech. Exploration Production Elf-Aquitaine, Pau, 12, 277-231

Praeg, D., Stoker M.S., Shannon P.M., Ceramicola S., HJelstuen B., LABERG J.S. \& Mathiesen A. (2005). - Episodic Cenozoic tectonism and the development of the NW European 'passive' continental margin. - Marine and Petroleum Geology, 22, 1007-1030

Reynaud J.-Y., Tessier B., Proust J-N., Dalrymple, R.W., Bourillet, J-F., De Batist M., Lericolais G., Berné S. \& Marsset T. (1999a). Architecture and sequence stratigraphy of a late Neogene incised valley at the shelf margin, Southern Celtic Sea. - J. Sed. Res., 69, 2, 351364 .

Reynaud J.-Y., Tessier B., Proust J-N., DAlrymple, R.W., Marsset T., De Batist M., Bourillet J-F. \& Lericolais G. (1999b). - Eustatic and hydrodynamic controls on the architecture of a deep shelf sand bank (Celtic Sea). - Sedimentology, 46, 703-721.

REYNAUd J.-Y. (1996). - Architecture et évolution d'un banc sableux de Mer Celtique méridionale. - Mémoire de doctorat, USTL, 256 p.

RUfFELL, A. (1995) - Evolution and Hydrocarbon prospectivity of the Brittany Basin (Western Approaches Trough), offshore north-west France. Marine and Petroleum Geology, 12, 4, 387-407

SHACKLETON, N.J. (1987) - Oxygen isotopes, ice volume and sea level. Quat. Sci. Rev., 6, 183-190

ShaCKLETON, N.J. \& OPDYKE, N.D. (1973) - Oxygen Isotope and Palaeomagnetic Stratigraphy of Equatorial Pacific Core V28-238: Oxygen Isotope Temperatures and Ice Volumes on a 10 (super 5) and 10 (super 6) Year Scale. Quat. Res., 3, 39-55.

SHAIL R.K. \& LEVERIDGE B.E., (2009). - The Rhenohercynian passive margin of SW England : Development, inversion and extensional reactivation. C. R. Geoscience, 341, 140-155.

THINON I. (1999). - Structure profonde de la Marge Nord Gascogne et du Bassin Armoricain. Mémoire de doctorat, Université de Bretagne Occidentale, $327 \mathrm{p}$.

UNDERHILl J.R. \& PATTERSON S., (1998). - Genesis of tectonic inversion structures : sesimic evidence for the development of key structures along the Purbeck-Isle of Wight Disturbance. - Journal of the Geological Society, London, 155, 975-992.

Van Vliet-Lanoë B., Laurent M., Hallegouët B., Margerel J.-P. Chauvel J.-J., Michel Y., Moguedet G., Trautman F. \& Vauthier S. (1998) - Le Mio -Pliocène du Massif armoricain. Données nouvelles. - C. R. Acad. Sci., Paris, 326, 333-340.

VAn Vliet-Lanoë B., MAnSy J.-L., Henriet J.-P., LAURent M. \& Vidier, J.-P. (2004). - Une inversion tectonique par étape : le Pas-de-Calais. Bull. Soc. Géol. Fr., 175, 2,175-197

VANHAUWAERT P. (1993). - Hoge-resolution reflectieseismische studie van neogene en kwartaire afzettingen in de keltische zee - Etude de sismique reflexion haute-résolution des terrains néogène quaternaires en Mer Celtique. - Unpublished diploma van licentiaat in de Geologie thesis, Universiteit Gent.

VANNEY J.R. (1977). -Géomorphologie de la marge continentale sudarmoricaine. - Société d'enseignement supérieur: Paris, 473 p.

Waelbroeck C., Labeyrie L., Michel E., Duplessy J.-C., McManus J.F., LAMBeck K., Balbon E. \& LABRAChERIE M. (2002) - Sea-level and deep water temperature changes derived from benthic Foraminifera isotopic records. Quat. Sci. Rev., 21, 295-305. 
Williams G.D., POWEll C.M. \& COOPER M.A., (1989). - Geometry and kinematics of inversion tectonics. In : COOPER M.A., WilliAMS G.D. eds, Inversion tectonics. Geological Society Special Publication, 44, 3-15.

Zaragosi, S., Auffret, G.A., Faugères, J.-C., Garlan, T., Pujol, C. \& Cortio, E. (2000). - Physiography and recent sediment distribution of the Celtic Deep-Sea Fan, Bay of Biscay. - Marine Geology, 169, 207-237.

ZARAGOSI S. (2001). Les systèmes turbiditiques profonds de la marge Celtique-Armoricaine (Golfe de Gascogne) :Physiographie et Evolution au cours des derniers 30000 ans. Rapport de doctorat, Université de Bordeaux I.

ZIEGLER, P.A. (1982). - Geological Atlas of Western and Central Europe. - Elsevier, Amsterdam, 130 p and enclosures.

ZIEGLER, P-A. (1987). - Evolution of the Western Approaches Trough. Tectonophysics, 137: 341-346.

ZIEGLER, P.A., (1990). - Geological atlas of western and central Europe. Shell Internationale Petroleum. In: Maatschapij B. V., Ed. Geol. Soc. Publishing House, The Hague, 239 p.

\section{Table caption}

\begin{tabular}{|c|c|c|c|c|c|}
\hline CRUISE & YEAR & AREA & SYSTEM & $\begin{array}{l}\text { CUMULATIVE } \\
\text { LENGTH (km) }\end{array}$ & REFERENCE \\
\hline $\begin{array}{l}\text { Levées } \\
\text { Bir_Hacheim } \\
(\text { BRGM) }\end{array}$ & $\begin{array}{l}1968- \\
1969\end{array}$ & Western Approaches & Sparker (7000 J) & 3300 & $\begin{array}{l}\text { [Andreieff et } \\
\text { al., 1972] }\end{array}$ \\
\hline Astrolabe, (BRGM) & 1970 & Western Channel & Sparker & 2100 & $\begin{array}{l}\text { [Boillot et al., } \\
\text { 1972] }\end{array}$ \\
\hline $\begin{array}{l}\text { Géo-Manche } 1 \text { et } 2 \\
(\mathrm{BRGM})\end{array}$ & $\begin{array}{l}1971- \\
1972\end{array}$ & Western Channel & Sparker (3000 J) & 3400 & $\begin{array}{l}\text { [Bouysse et } \\
\text { al., } \\
1974]\end{array}$ \\
\hline BGS & 1978 & Western Channel & $\begin{array}{l}\text { Air gun and } \\
\text { Sparker }(1-3 \mathrm{~kJ})\end{array}$ & unknown & [Evans, 1990] \\
\hline Sédimanche 1 et 2 & $\begin{array}{l}1991- \\
1993\end{array}$ & $\begin{array}{l}\text { Ouessant Zone, Kaiser- } \\
\text { I-hind Zone, } \\
\text { Hurd Deep Zone }\end{array}$ & $\begin{array}{l}\text { Sparker \& EM12 } \\
\text { \& EM1000 }\end{array}$ & 1500 & $\begin{array}{l}\text { [Lericolais, } \\
\text { 1997] }\end{array}$ \\
\hline Belgica-Starfish & 1992 & Celtic Sea & Sparker & unknown & $\begin{array}{l}\text { [Vanhauwaert, } \\
\text { 1993] }\end{array}$ \\
\hline
\end{tabular}

Table 1 : Previous available seismic data collected from 1968 to 1998 across the French sector of the Western Approaches. 


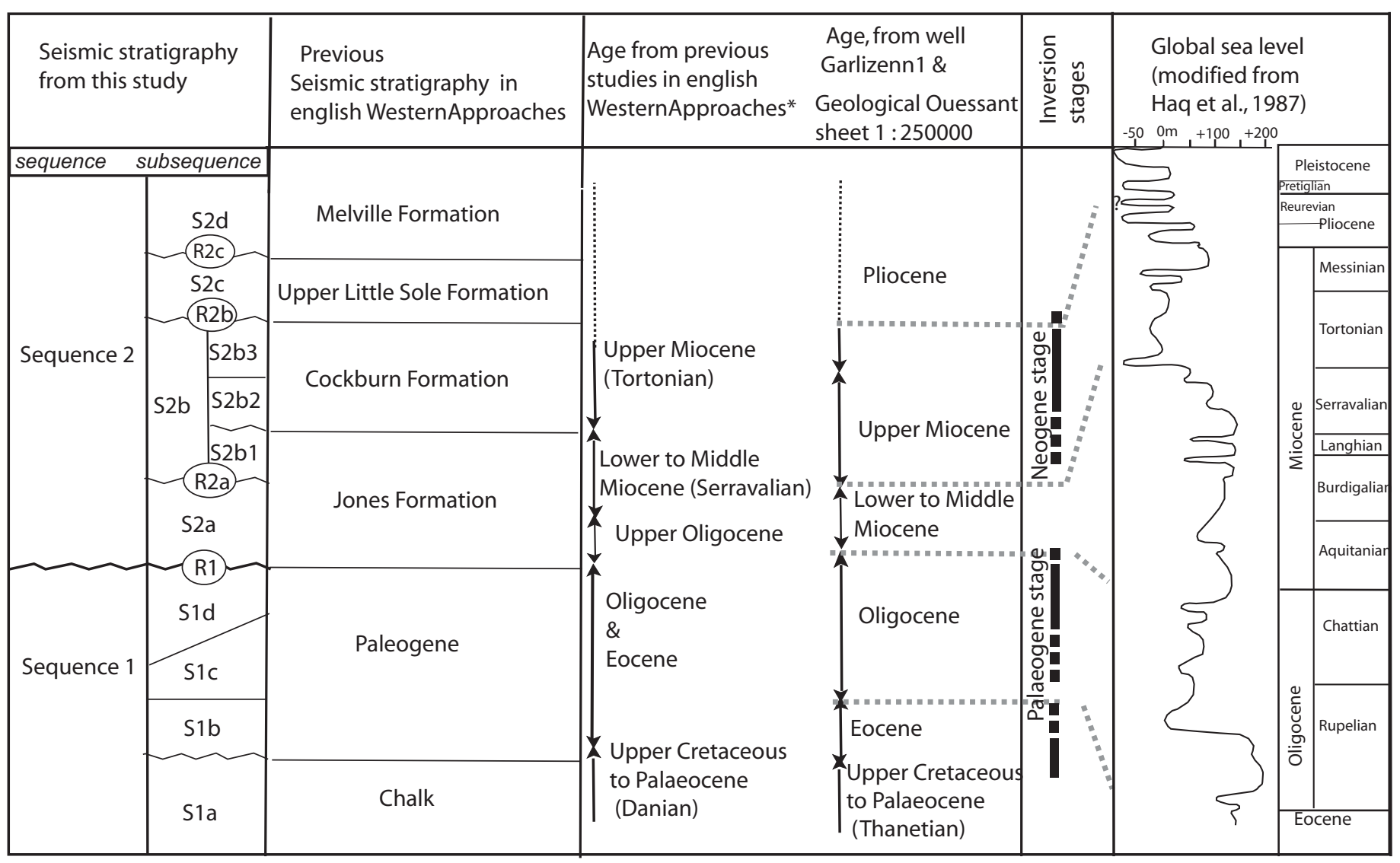

${ }^{*}$ References in the text 
Table 2 : Seismic stratigraphy from the French and English sectors of the Western Approaches and chronostratigraphic attributions. Correlation to the global sea-level curve (modified from Haq et al., 1987) and to the main inversion stages.

\section{Figure captions}

Fig. 1. - Geological and structural framework of Western Approaches margin; adapted from Blois et al., [1991] and Bourillet et al., [2003]. LS: Lizard suture; MMF: Médi-Manche Fault; AUF: AlderneyUshant Fault (or Aurigny Ouessant Fault); NAZS: North Armorican Shear Zone; SASZ: South Armorican Shear Zone; Sh. C.: Shamrock Canyon; Bl. C.: Blackmud Canyon; DSF: Deep Sea Fan.

Fig. 1. - Cadre géologique et structural de la marge des Approches Occidentales ; adapté d'après Blois et al, [1991] and Bourillet et al., [2003]. LS : Suture du Vap Lizard ; MMF : Faille Médio-Manche ; AUF : Faille Aurigny Ouessant ; NAZS : cisaillement nord armoricain ; SAZS : cisaillement sud armoricain ; Sh. C. : Canyon de Shamrock ; Bl. C : Canyon de Blackmud ; DSF : Deep sea fan.

Fig. 2. - Location of seismic lines and boreholes used in study. Sections highlighted are shown in the paper.

Fig. 2. - Carte de localisation des profils sismiques et forages utilisées dans cette étude. Les sections surlignées sont représentées dans l'article.

Fig. 3. - Sparker Seismic line MOC12 (2 sections) and interpretation. Location also shown in Figure 2. The faut Flt1 is located. Correspondence of the sequences and surfaces are shown in Table 2.

Fig. 3. - Profil sismique sparker MOC 12 (2 sections) et interprétation. Localisation également sur figure 2. La faille Flt1 est localisée. Les correspondances des séquences et surfaces indiquées figurent dans le tableau 2.

Fig. 4. - Extract of the sparker seismic line MOC 06 and interpretation showing the syntectonic nature of the S1d sequence. Location also in Figure 2. Correspondence of the sequences and surfaces are shown in Table 2. 
Fig. 4. - Extrait du profil sismique sparker MOC 06 montrant le caractère syntectonique de l'séquence S1d. Localisation sur figure 2. Les correspondances des séquences et surfaces indiquées figurent dans le tableau 2.

Fig.5. - Interpretation of the Sparker Seismic line MOC 08 showing the Neogene inner sequences S2b1 to S2b3 prograding towards the northwest. Location also shown in Figure 2. The faut Flt1 and Flt 2 are located. Correspondence of the sequences and sufaces are shown in Table 2.

Fig. 5. - Interprétation du Profil sismique sparker MOC 08 (2 sections) montrant les séquences internes S2b1 à S2b3 progradant vers le NW. Localisation également sur figure 2. Les failles FLt1 et FLt2 sont localisées. Les correspondances des séquences et surfaces indiquées figurent dans le tableau 2.

Fig. 6. - Comparison of the two seismic lines 78/04/53 from the BGS and MOC 07. The base of the Cockburn Formation corresponds to the base of the S2b2 sequence. See also Figure 2 for location.

Fig. 6. - Comparaison des deux lignes sismiques parallèles 78/04/53 du BGS et MOC 07. La base de la Formation de Cockburn correspond à la base de la séquence S2b2. Voir la figure 2 pour la localisation.

Fig. 7. - Isochron map of the base of Neogene sequence S2 (R1 unconformity).

Fig. 7. - Carte isochrone de la base de la séquence néogène S2 (discordance R1).

Fig. 8. - Isochron map of the base of Neogene sequence S2b, intra Jones Formation (R2a unconformity).

Fig. 8. - Carte Isochrone de la base de la séquence néogène S2b, intra Formation Jones (discordance R2a).

Fig. 9. - Isochron map of the base of Neogene sequence S2c corresponding to the base of the Upper Little Sole Formation delimiting the base of the palaeovalleys of the Western Approaches (R2c unconformity). 
Fig. 9. - Carte Isochrone de la base de la séquence néogène S2c correspondant à la base de la Formation de la Petite Sole supérieure formant la base des paléovallées des Approches Occidentales (discordance R2c).

Fig. 10. - Correlation of the Galizenn1 well with the MOC 04 sparker seismic line (extract).

Fig. 10. - Corrélation du forage industriel Garlizenn1 avec le profil sismique MOC04 (extrait).

Fig. 11. - Extract of the sparker seismic line MOC28 and interpretation showing the drag of the onlapping reflectors from the sequence $\mathrm{S} 2 \mathrm{~b}$ along the hanging wall of the North Iroise Fault zone -NIF- at the SSE. Location in Figure 2. Correspondence of the sequences and surfaces are shown in the Table 2.

Fig. 11. - Extrait du profil sismique sparker MOC28 et interprétation montrant le rebroussement de la terminaison des réflecteurs en biseaux d'aggradation le long de la zone faillée Nord Iroise -NIF- au SSE. Localisation sur figure 2. Les correspondances des séquences et surfaces indiquées figurent dans le tableau 2. 


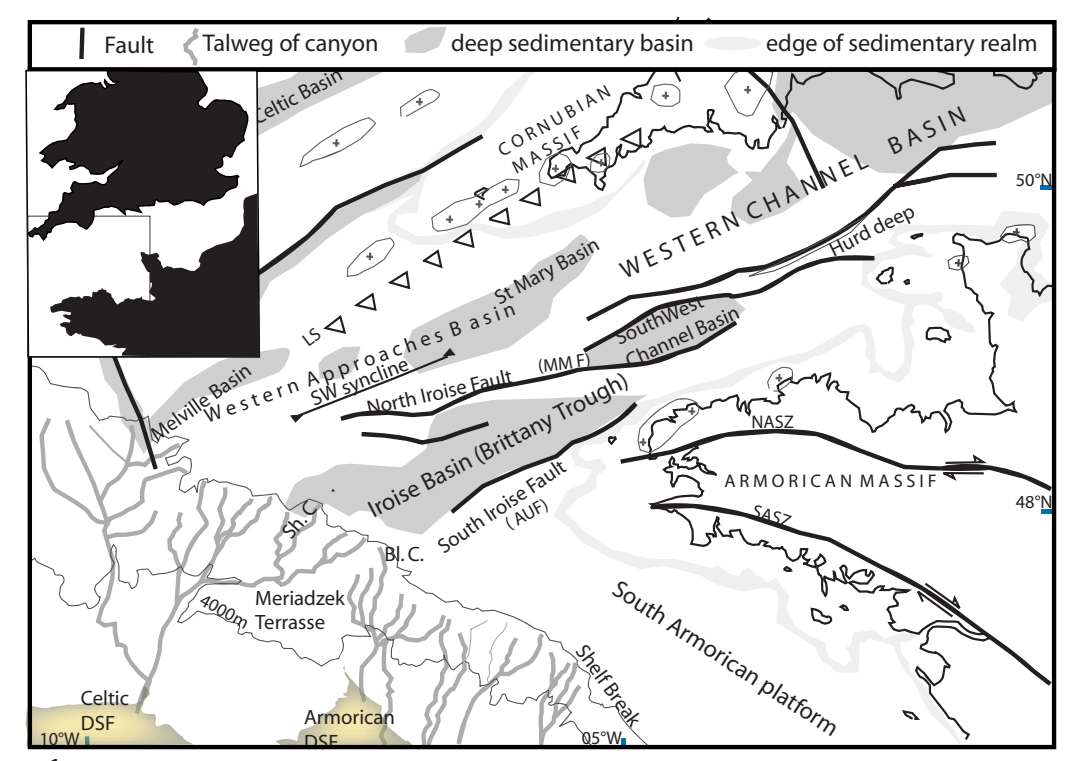

Figure $1:$ Geological and structural framework of Western Approaches margin; adapted from Blois et al., (1991) and Bourillet et al., (2003) ArmoricanShear Zone :SASZ: South A or Mican Shear Zone; S A C. Shamrock Canyon :BLC Blackmud Canyon : DSF : Deep Sea
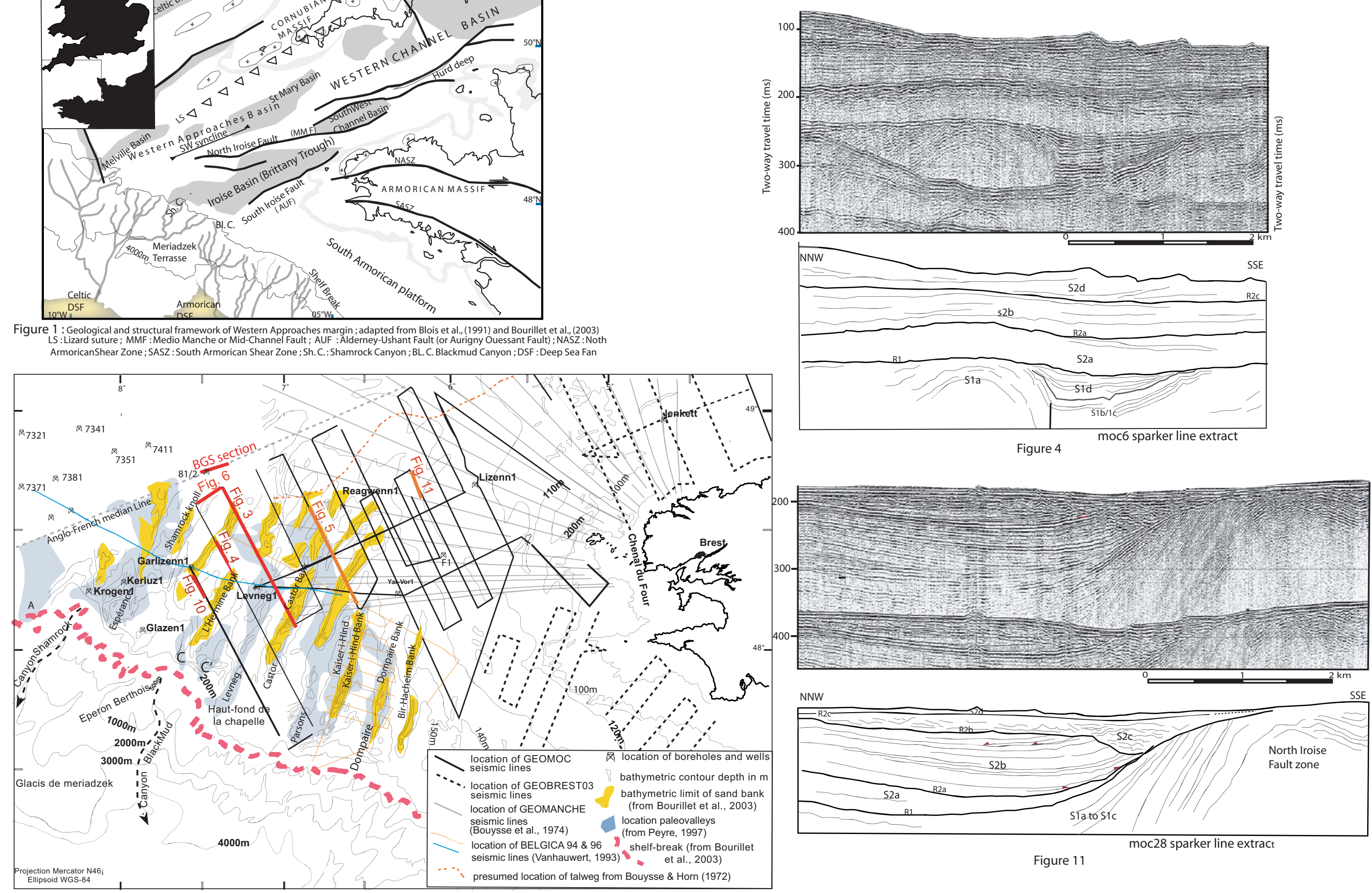

Figure 11

moc28 sparker line extract 

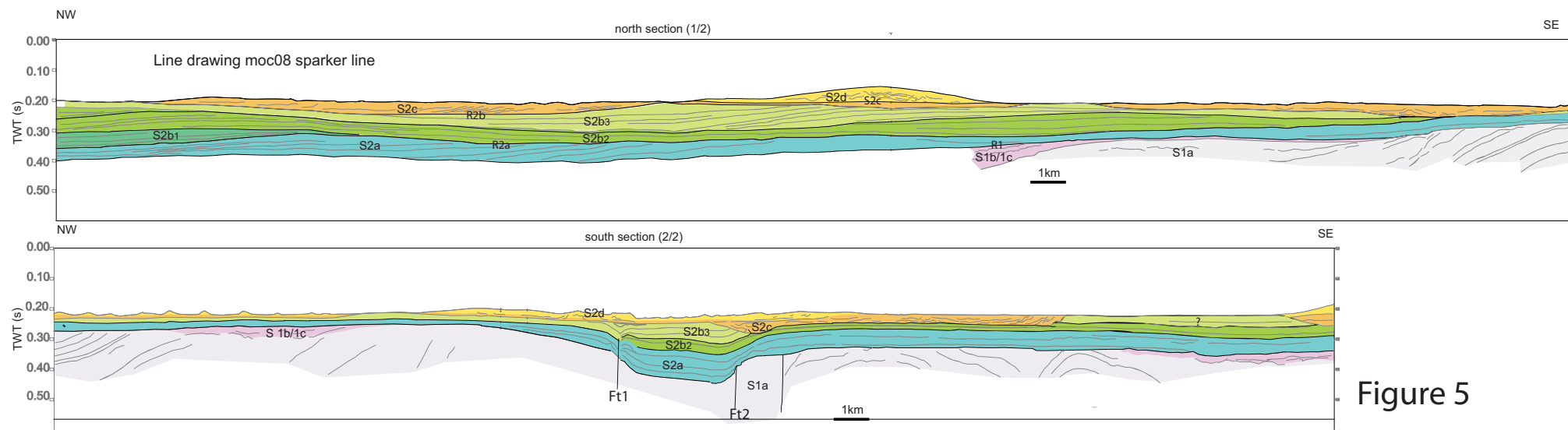

\section{1}

\section{Figure 5}
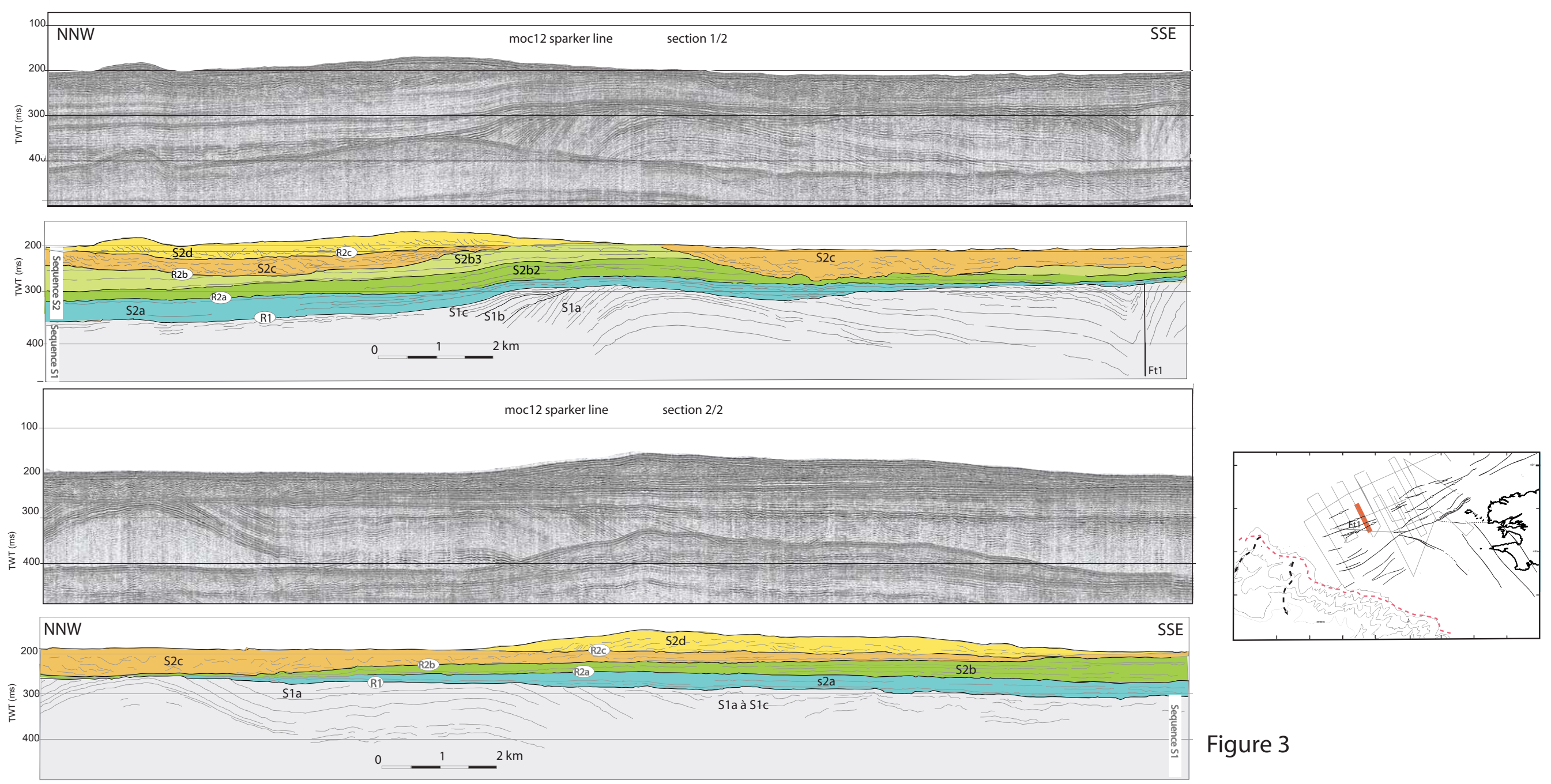

Figure 3 

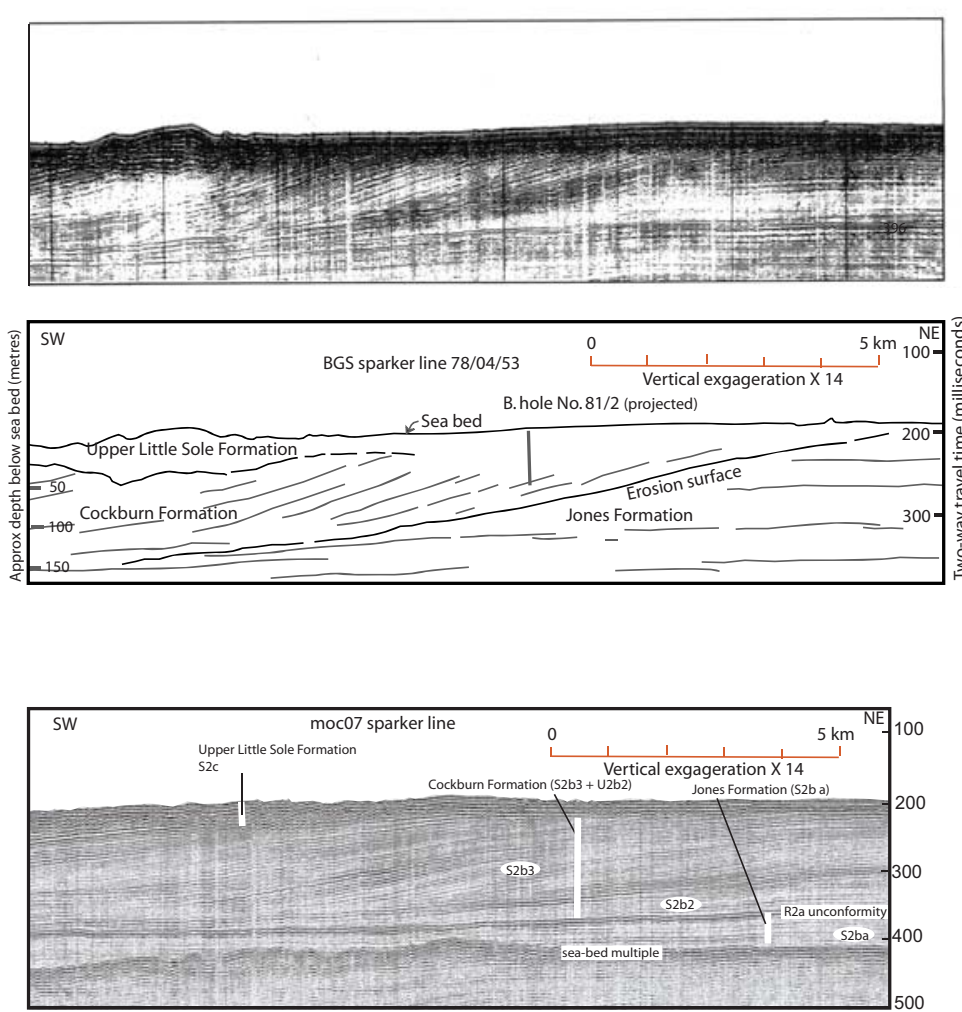

Figure 6

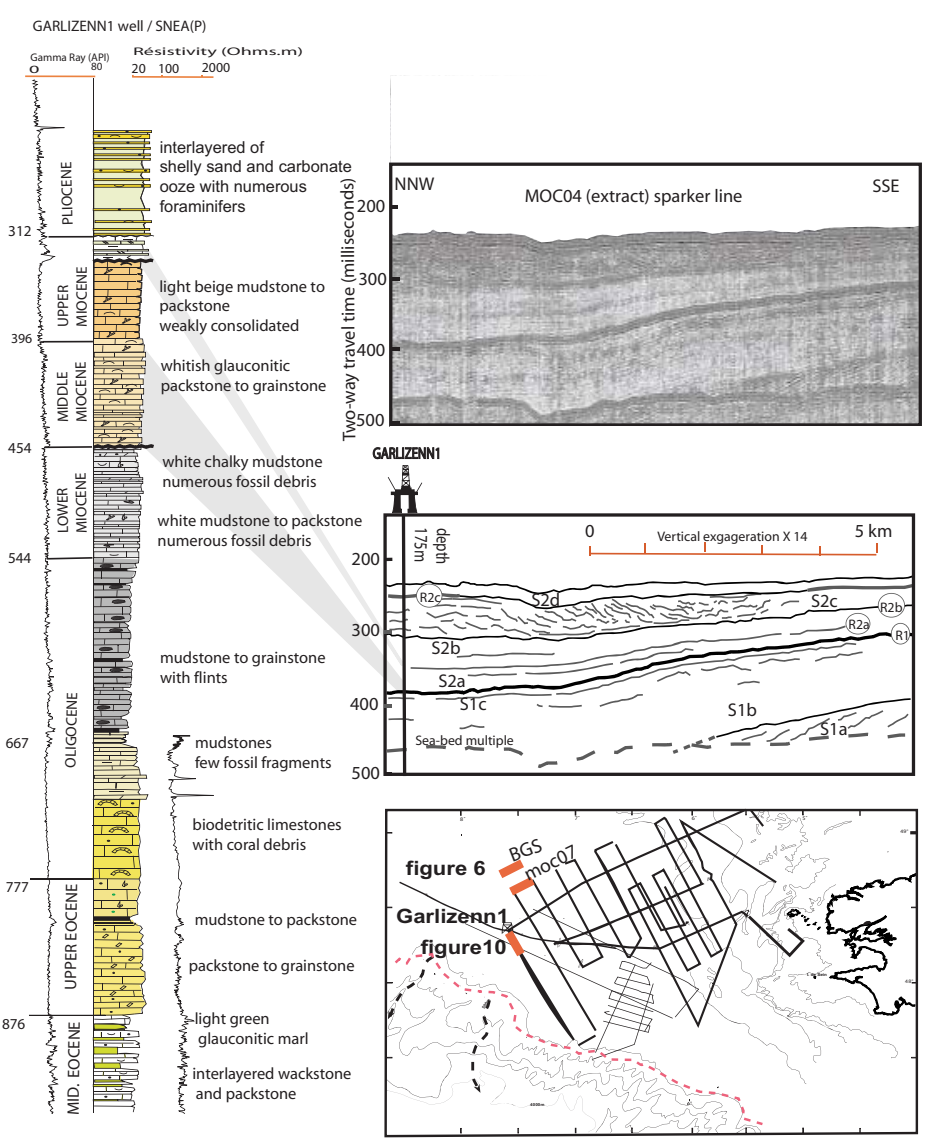

Figure 10

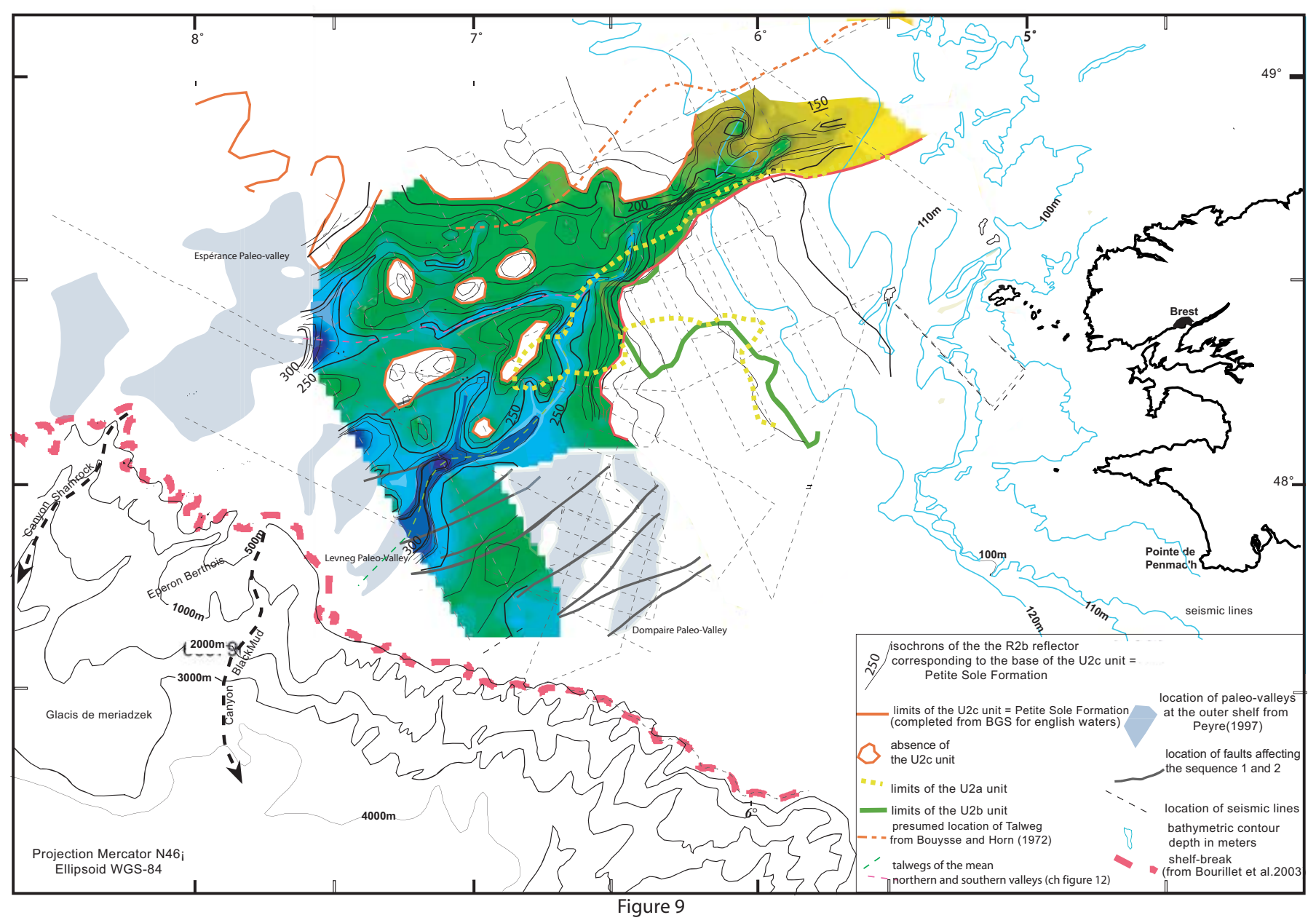




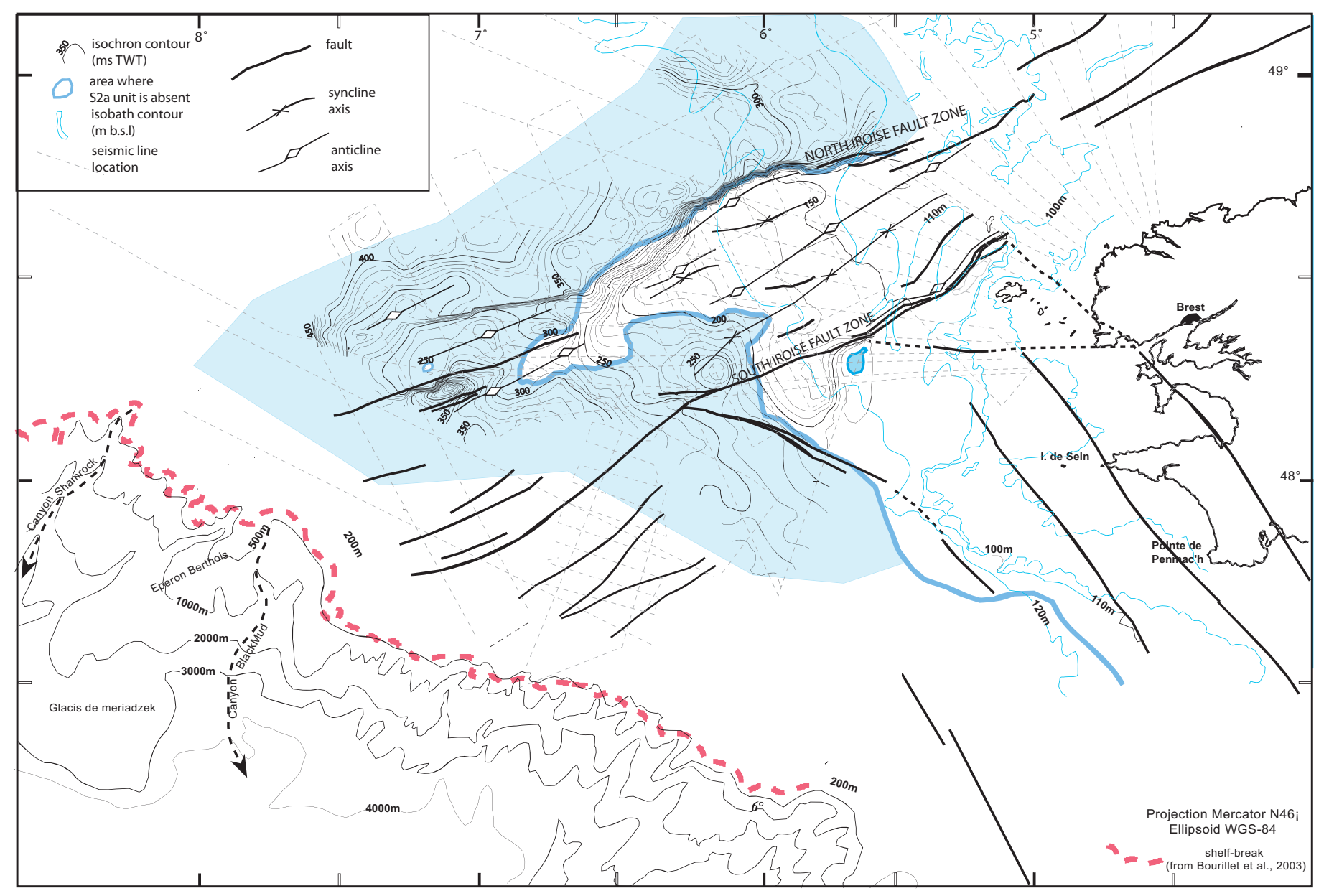

Figure 7

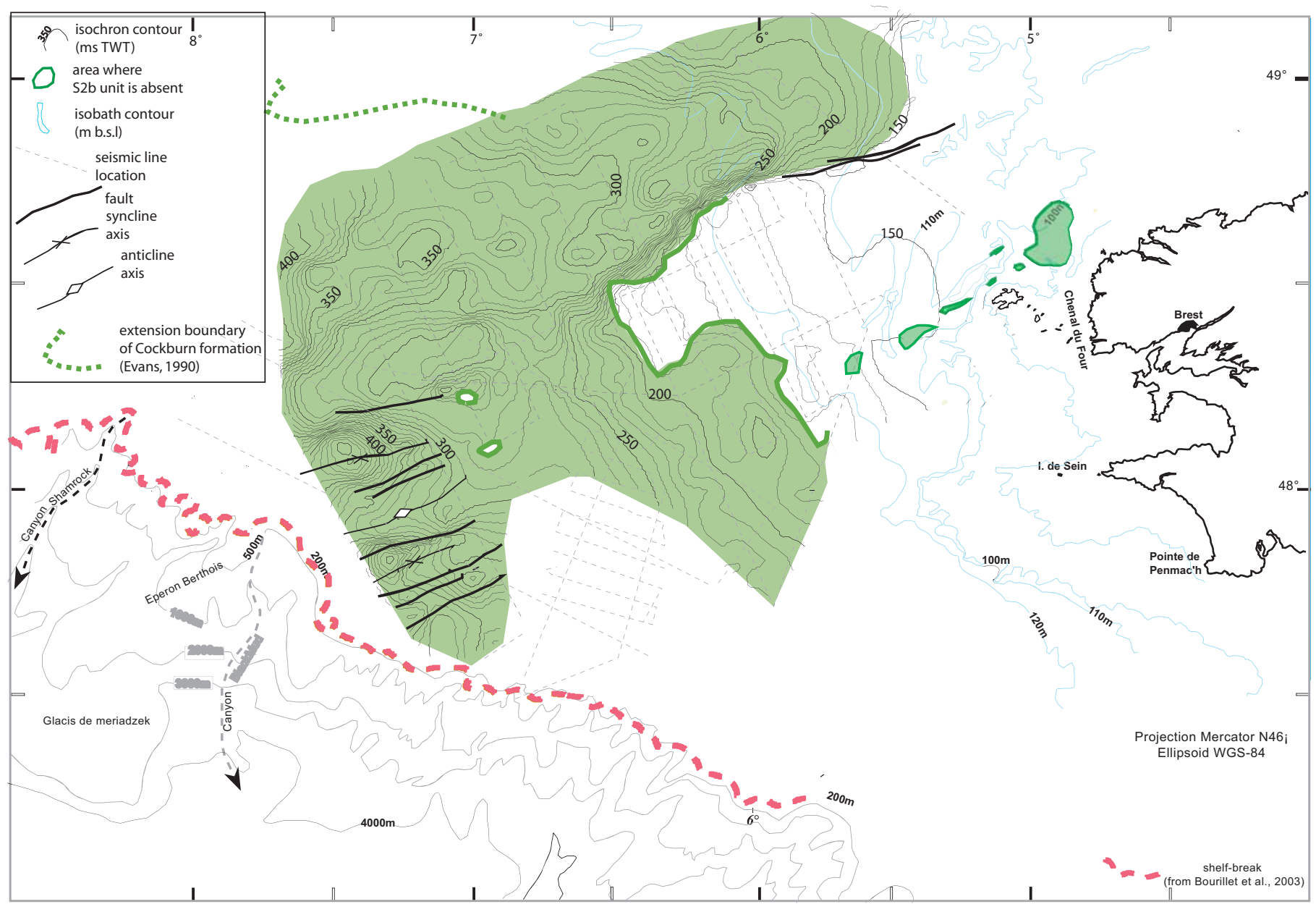

Figure 8 